\title{
Effects of Intravitreal Injection of Ranibizumab and Aflibercept on Corneal Endothelium and Central Corneal Thickness
}

\author{
Mehmet Coskun
}

Department of Ophthalmology, Karabük University Faculty of Medicine, Karabük, Turkey

\begin{abstract}
Objectives: This study was an evaluation of intravitreal injections of ranibizumab (IVR) and aflibercept (IVA) administered to the corneal endothelium.

Methods: Thirty eyes of 30 patients made up the IVR injection group and 30 eyes of another 30 patients were recruited as the IVA injection group. Specular microscopy results before the injection, on the $1^{\text {st }}, 7^{\text {th }}$, and $30^{\text {th }}$ days were examined. Central corneal thickness (CCT), endothelial cell density (CD), coefficient of variation (CV), and hexagonality (HEX) values were recorded.

Results: No difference was seen between the groups with respect to gender $(p=0.057)$. No significant difference was seen in CCT measurements in the IVR or the IVA group $(p=0.08, p=0.16$, respectively). Nor was a significant difference seen in the IVR group in terms of CD ( $p=0.85)$; however, a statistically significant difference was detected in the IVA group $(p=0.03)$. Furthermore, no significant difference was seen in the IVR or the IVA group with regard to $C V(p=0.12, p=0.17$, respectively), and no significant difference was seen in the IVA group with respect to HEX values between measurements intervals ( $p>0.05)$; however, a significant difference was found in the IVR group $(p=0.02)$.

Conclusion: Neither IVR nor IVA affected the CCT or CV values. The CD did not change significantly in the IVR group, whereas in the IVA group, the CD values of the first day after the injection were high, although they had returned to normal on the $30^{\text {th }}$ day. In the IVR group, a statistically significant difference was seen in terms of the HEX values.

Keywords: Aflibercept, anti-vascular endothelial growth factor, intravitreal injection, ranibizumab, specular microscopy.
\end{abstract}

\section{Introduction}

Vascular endothelial growth factor (VEGF) is the most important factor in ocular angiogenesis. Recently developed anti-VEGF agents have revolutionized the treatment of many retinal diseases. These agents affect both neovascularization and permeability, and therefore, in many diseases that could result in vision loss, visual acuity can be preserved or increased $(I, 2)$.

Under normal physiological conditions, VEGF is secreted by the stroma, epithelium, and the endothelial layers of the cornea. VEGF is produced in large amounts by the vessels of the limbus and nascent stromal vessels, as well as by keratocytes, but to a lesser extent. Moreover, it has been determined in experimental studies that VEGF receptors exist on the corneal endothelium (3). Anti-VEGF agents could be used for the treatment of pathological conditions in the cornea, such as corneal neovascularization, as well as retinal disease.

Petsoglou et al. (4) observed a significant regression of corneal neovascularization after subconjunctival bevacizumab injections with no adverse effects in terms of central corneal

Address for correspondence: Mehmet Coskun, MD. Department of Ophthalmology, Karabük University

Faculty of Medicine, Karabük, Turkey

Phone: +90 5052934404 E-mail: drmehmetcoskun@mynet.com

Submitted Date: May 08, 2018 Accepted Date: July 02, 2018 Available Online Date: July 12, 2018

${ }^{\odot}$ Copyright 2018 by Beyoglu Eye Training and Research Hospital - Available online at www.beyoglueye.com 
thickness, intraocular pressure, or the number of endothelial cells when compared with saline injections. Chalam et al. (5) reported in their in vitro safety profile study that bevacizumab had no cytotoxic effect in human corneal cells up to a concentration of $4 \mathrm{mg} / \mathrm{mL}$.

The aim of the present study was to evaluate the potential adverse effects of intravitreal injections of different antiVEGFs in patients with nonproliferative diabetic retinopathy and macular edema and to compare the results by investigating changes to the corneal endothelium.

\section{Methods}

Sixty eyes of 60 patients who received intravitreal injections due to diabetic retinopathy and macular edema were investigated retrospectively. The patients were recruited from among individuals who presented at the eye disease clinic of the Medical Faculty Hospital of Karabuk University. Approval for the study was obtained from the ethics committee of Karabuk University. IVR was injected into 30 eyes of 30 patients, and IVA was injected into 30 eyes of another 30 patients. Ranibizumab (Lucentis; Novartis International AG, Basel, Switzerland) and aflibercept (Eylea; Bayer AG, Leverkusen, Germany) were injected at doses of $0.5 \mathrm{mg} / 0.05$ $\mathrm{mL}$ and $2 \mathrm{mg} / 0.05 \mathrm{~mL}$, respectively. Patients with an ocular disease, those who had used an ocular medication or who had previously undergone ocular surgery were excluded. Specular microscopy measurements were performed using an SP-IP device (Topcon Medical Systems, Inc., Oakland, NJ, USA). Central corneal thickness (CCT), endothelial cell density $(C D)$, coefficient of variation (CV), and hexagonality (HEX) parameter values were recorded before the injection $(O)$, on the $1^{\text {st }}$ day $(I), 7^{\text {th }}$ day (7), and the $30^{\text {th }}$ day (30) after the injection. The parameters during the intervals were compared between the groups.

SPSS for Windows, Version 16.0 (SPSS, Inc., Chicago, IL, USA) was used for the statistical analysis. A chi-square test was used to compare the groups with respect to gender. Student's t-test was used to determine differences between the groups. Measurements before the injection, on the Ist day, $7^{\text {th }}$ day, and the $30^{\text {th }}$ day after injection were compared using Friedman analysis of variance (ANOVA). Wilcoxon's matched-pairs test was used as a post hoc test after the ANOVA analysis. A 2-tailed technique was used and the significance level was set at $p<0.05$.

\section{Results}

The mean age of the IVR and IVA groups was $60.70 \pm 5.70$ years and $61.30 \pm 6.29$ years, respectively. There was no significant difference between the therapy groups with respect to age $(p=0.75)$. Eighteen men and 12 women were included in IVR group, and 17 men and 13 women comprised the
IVA group. There was no significant difference between the groups with respect to gender $(p=0.057)$.

There was no statistically significant difference in the CCT value after the injection between the IVR and the IVA groups ( $p=0.08$ and $p=0.16$, respectively) (Table $I$ and 2 ).

No statistically significant difference was observed in the IVR group in terms of $C D$ values between measurement intervals $(p=0.85)$ (Table 3$)$; however, a significant difference was observed in the IVA group $(p=0.03)$. Binary comparisons made with the Wilcoxon test revealed that this difference began in the earliest period: the $C D$ value in the first week

Table I. Median, minimum, and maximum values of central corneal thickness measurements before injection (OCCT), on the Ist day after injection (ICCT), $7^{\text {th }}$ day after injection (7CCT), and the $30^{\text {th }}$ day after injection (30CCT) in the ranibizumab group.

\begin{tabular}{lcccc}
\multicolumn{1}{c}{} & OCCT & ICCT & 7CCT & 30CCT \\
\hline $\mathrm{N}$ & & & & \\
\multicolumn{1}{c}{ Valid } & 30 & 30 & 30 & 30 \\
$\quad$ Missing & 0 & 0 & 0 & 0 \\
Median & 537.00 & 538.00 & 536.50 & 537.50 \\
Minimum & 502 & 479 & 496 & 492 \\
Maximum & 562 & 560 & 590 & 553 \\
\hline
\end{tabular}

Table 2. Median, minimum, and maximum values of central corneal thickness measurements before injection (OCCT), on the Ist day after injection (ICCT), $7^{\text {th }}$ day after injection (7CCT), and the $30^{\text {th }}$ day after injection (30CCT) in the aflibercept group.

\begin{tabular}{lcccc} 
& OCCT & ICCT & 7CCT & 30CCT \\
\hline $\mathrm{N}$ & & & & \\
\multicolumn{1}{c}{ Valid } & 30 & 30 & 30 & 30 \\
$\quad$ Missing & 0 & 0 & 0 & 0 \\
Median & 522.50 & 520.50 & 519.00 & 518.50 \\
Minimum & 467 & 467 & 470 & 468 \\
Maximum & 597 & 600 & 596 & 582 \\
\hline
\end{tabular}

Table 3. Median, minimum, and maximum endothelial cell density measurements in the ranibizumab group before injection (OCD), on the $I^{\text {st }}$ day after injection (ICD), $7^{\text {th }}$ day after injection $(7 C D)$, and the $30^{\text {th }}$ day after injection $(30 C D)$.

OCD ICD 7CD 30CD

N

\begin{tabular}{lcccc} 
Valid & 30 & 30 & 30 & 30 \\
Missing & 0 & 0 & 0 & 0 \\
Median & 2667.50 & 2729.00 & 2689.00 & 2695.00 \\
Minimum & 1078 & 1139 & 1144 & 1154 \\
Maximum & 3015 & 2942 & 3324 & 3161 \\
\hline
\end{tabular}


$\left(2515.00\right.$ cells $\left./ \mathrm{mm}^{2}\right)$ was significantly higher than the posttreatment level $\left(2342.00\right.$ cells $\left./ \mathrm{mm}^{2}\right)$ at week I $(p=0.02)$. The differences between the other intervals were not significant (Table 4). This result indicated that the earlier CD disorder was resolved quickly.

No statistically significant difference was observed in terms of CV between the measurement intervals in either the IVR or the IVA group $(p=0.12$ and $p=0.17$, respectively) (Table 5 and Table 6).

In the IVR group, a statistically significant difference was seen in the HEX values $(p=0.02)$. The median OHEX value

Table 4. Median, minimum, and maximum endothelial cell density measurements in the aflibercept group before injection (OCD), on the $I^{\text {st }}$ day after injection (ICD), $7^{\text {th }}$ day after injection (7CD), and the $30^{\text {th }}$ day after injection $(30 C D)$.

\begin{tabular}{lcccc} 
& OCD & ICD & 7CD & 30CD \\
\hline $\mathrm{N}$ & & & & \\
$\quad$ Valid & 30 & 30 & 30 & 30 \\
$\quad$ Missing & 0 & 0 & 0 & 0 \\
Median & 2342.00 & 2515.00 & 2372.00 & 2331.50 \\
Minimum & 1969 & 2006 & 1974 & 2038 \\
Maximum & 2975 & 3012 & 2670 & 3030 \\
\hline
\end{tabular}

Table 5. Median, minimum, and maximum coefficient of variation before injection $(0 \mathrm{CV})$, on the $\mathrm{I}^{\text {st }}$ day after injection $(\mathrm{ICV}), 7^{\text {th }}$ day after injection $(7 \mathrm{CV})$, and the $30^{\text {th }}$ day after injection $(30 \mathrm{~V})$ in the ranibizumab group.

\begin{tabular}{lcccc} 
& OCV & ICV & 7CV & 30CV \\
\hline $\mathrm{N}$ & 30 & 30 & 30 & 30 \\
$\quad$ Valid & 0 & 0 & 0 & 0 \\
$\quad$ Missing & 31.50 & 32.00 & 30.00 & 31.00 \\
Median & 27 & 23 & 25 & 29 \\
Minimum & 39 & 42 & 38 & 42 \\
Maximum & & & &
\end{tabular}

Table 6. Median, minimum, and maximum coefficient of variation before injection $(\mathrm{OCV})$, on the $\mathrm{I}^{\text {st }}$ day after injection $(\mathrm{ICV}), 7^{\text {th }}$ day after injection $(7 \mathrm{CV})$, and the $30^{\text {th }}$ day after injection $(30 \mathrm{~V})$ in the aflibercept group.

\begin{tabular}{lcccc} 
& OCV & ICV & 7CV & 30CV \\
\hline $\mathrm{N}$ & 30 & 30 & 30 & 30 \\
$\quad$ Valid & 0 & 0 & 0 & 0 \\
$\quad$ Missing & 30.00 & 30.00 & 31.00 & 31.00 \\
Median & 22 & 23 & 25 & 24 \\
Minimum & 41 & 38 & 38 & 45 \\
Maximum & & & &
\end{tabular}

was greater than the $30 \mathrm{HEX}$ value as a result of progressive changes in HEX from the pretreatment period to the last examination $(p=0.007)$ (Table 7$)$. There were no statistically significant differences in HEX values in the IVA group between measurement intervals $(p=0.69)$ (Table 8).

\section{Discussion}

Anti-VEGFs are effective, recent agents used for the treatment of many ocular diseases. Ranibizumab, which is produced with recombinant monoclonal antibody technology, is a human anti-VEGF antibody fragment that is able to bind to all isoforms of VEGF (6). Aflibercept binds VEGFR-I and VEGFR-2, which are on VEGF-A, with a higher affinity than bevacizumab $(7,8)$. It also inhibits VEGF-B and placental growth factor. In vitro studies demonstrated that VEGF and its receptor were expressed on the cornea and anterior chamber $(9,10)$. In vitro conditions revealed that neither bevacizumab nor ranibizumab had a toxic effect on the corneal epithelium or the retina, and to date, routine clinical applications have not caused toxicity (I I-I3). However, only a limited number of in vivo studies have evaluated the effects of intravitreal anti-VEGF injections on the corneal epithelium (I4-16). Furthermore, we found no studies investigating the effects of aflibercept on the corneal epithelium.

Table 7. Median, minimum, and maximum hexagonality values before injection (OHEX), on the $1^{\text {st }}$ day after injection (IHEX), $7^{\text {th }}$ day after injection (7HEX), and the $30^{\text {th }}$ day after injection (3OHEX) in the ranibizumab group.

\begin{tabular}{lcccc} 
& ÖHEX & I HEX & 7HEX & 30HEX \\
\hline $\mathrm{N}$ & 30 & 30 & 30 & 30 \\
$\quad$ Valid & 0 & 0 & 0 & 0 \\
$\quad$ Missing & 52.50 & 54.50 & 53.00 & 49.50 \\
Median & 29 & 35 & 38 & 19 \\
Minimum & 66 & 68 & 68 & 62 \\
Maximum & & & & \\
\hline
\end{tabular}

Table 8. Median, minimum, and maximum hexagonality values before injection (OHEX), on the $1^{\text {st }}$ day after injection (IHEX), $7^{\text {th }}$ day after injection (7HEX), and the $30^{\text {th }}$ day after injection (30HEX) in the aflibercept group.

\begin{tabular}{lcccc} 
& OHEX & IHEX & 7HEX & 30HEX \\
\hline $\mathrm{N}$ & & & & \\
$\quad$ Valid & 30 & 30 & 30 & 30 \\
$\quad$ Missing & 0 & 0 & 0 & 0 \\
Median & 52,00 & 51,50 & 51,00 & 52,00 \\
Minimum & 41 & 48 & 47 & 30 \\
Maximum & 60 & 65 & 62 & 61 \\
\hline
\end{tabular}


Yourek et al. (9) reported that although VEGF, VEGF$\mathrm{I}$, and VEGF-2 receptors were present in avascular tissue, such as the cornea, corneal avascularization was protected by balancing fms-related tyrosine kinase I.In a series of 5 cases, Bayar et al. (17) observed condensed corneal edema after a bevacizumab injection, which might have been the result of inhibition of the immune system activation feature of VEGF in limbal vessels. However, no pathological corneal endothelium was detected and corneal edema was treated with steroids in conjunction with antibiotics within 10 days in all cases. According to their study, it could be concluded that bevacizumab might cause morphological and immunological changes in the corneal endothelium.

VEGF is normally secreted by the stroma, the epithelium, and the endothelium of the cornea, but it is also secreted from limbal vessels and keratocytes, albeit to a lesser extent. It can be secreted in large amounts in pathological conditions by newly developed stromal vessels. In experimental studies, it has been observed that VEGF receptors were present in the corneal endothelium. It was reported that I week after an intravitreal injection of either bevacizumab (IVB) orranibizumab (IVR), VEGF levels decreased by at least I0fold in the aqueous humour, and anti-VEGF antibodies were detected in the aqueous humour 29 days after injection (18).

Cho et al. (19) compared the CD in patients aged 23 to 83 years with type I and non-type I diabetes mellitus (DM). The $C D$ was significantly lower in diabetics $(2577.2 \pm 27.3$ cells/ $\mathrm{mm}^{2}$ ) compared with nondiabetic subjects $(2699.9 \pm 38.7$ cells/ $\left.\mathrm{mm}^{2}\right)(p=0.0 \mathrm{l})$. The CD was $2617.6 \pm 34.3 \mathrm{cells} / \mathrm{mm}^{2}$ in patients with $\leq 10$ years of DM and $2525.7 \pm 38.3$ cells $/ \mathrm{mm}^{2}$ in those with $>10$ years of DM. In terms of $C D$, the difference was not significant $(p=0.07)$. Other parameters, such as $C V$, HEX, irregularity, and CCT were significantly higher in patients with DM than in the non-DM group $(p=0.00 I)$. However, Arslan et al. (20) reported that DM had no negative effect on endothelium morphology.

Chen et al. (2I) reported that they found no significant difference in terms of corneal endothelium count, polymorphism, polymegathism ratio, or CCT after a single dose of $2.5 \mathrm{mg}$ bevacizumab after 6 months. Benitez-Herrero et al. (14) reported no significant difference with regard to $C D$, $\mathrm{CCT}, \mathrm{CV}$, or HEX ratios when they compared these parameters before injection, following 3 monthly injections, and 6 months after the last injection in 52 patients with age-related macular degeneration.

Hosny et al. (22) showed that intracameral injections of $1.25 \mathrm{mg} / 0.05 \mathrm{~mL}$ IVB caused no structural changes of corneal endothelium morphology. Furthermore, Lichtinger et al. (23) found no statistically significant difference in terms of $C D$, CV, HEX, or CCT parameters before and 6 months after 3 combined subconjunctiva bevacizumab injections for the treatment of corneal neovascularization. Kim et al. (24) also compared intracameral injections of $0.05 \mathrm{~mL}$ bevacizumab with $0.05 \mathrm{~mL}$ bevacizumab plus balanced salt solution and concluded that bevacizumab had no negative effect on CCT or CD, and thus it could be used safely.

In our study, we observed no significant differences in CV over time between the IVR and IVA groups. In the IVA group, HEX values in the post-injection periods showed no significant difference compared with the pre-injection period. However, HEX values were significantly decreased at the 30thday measurement in the IVR group.

The limitations of our study are the number of patients included and the short period of patient follow-up. Furthermore, the tissue area analyzed with specular microscopy was just a 3-mm thick layer of cornea. Thus, evaluation of the cornea periphery was not possible, especially the area close to the limbus, which is rich for another blind side.

To the best of our knowledge, this is the first study to investigate the effect of aflibercept. Moreover, the decrease in HEX values in the IVR group is a new topic of discussion. We offer this study as a contribution to the current literature.

\section{Disclosures}

Peer-review: Externally peer-reviewed.

Conflict of Interest: None declared.

\section{References}

I. Kim LA, D'Amore PA. A brief history of anti-VEGF for the treatment of ocular angiogenesis. Am J Pathol 2012;181:376-9.

2. Kaiser PK. Antivascular endothelial growth factor agents and their development: therapeutic implications in ocular diseases. Am J Ophthalmol 2006; 142:660-8. [CrossRef]

3. Gan L, Fagerholm P, Palmblad J. Vascular endothelial growth factor (VEGF) and its receptor VEGFR-2 in the regulation of corneal neovascularization and wound healing. Acta Ophthalmol Scand 2004;82:557-63. [CrossRef]

4. Petsoglou C, Balaggan KS, Dart JK, Bunce C, Xing W, Ali RR, et al. Subconjunctival bevacizumab induces regression of corneal neovascularisation: a pilot randomised placebo-controlled double-masked trial. Br J Ophthalmol 2013;97:28-32. [CrossRef]

5. Chalam KV, Agarwal S, Brar VS, Murthy RK, Sharma RK. Evaluation of cytotoxic effects of bevacizumab on human corneal cells. Cornea 2009;28:328-33. [CrossRef]

6. Costa RA, Jorge R, Calucci D, Cardillo JA, Melo LA Jr, Scott IU. Intravitreal bevacizumab for choroidal neovascularization caused by AMD (IBeNA Study): results of a phase I dose-escalation study. Invest Ophthalmol Vis Sci 2006;47:4569-78.

7. Stewart MW, Rosenfeld PJ, Penha FM, Wang F, Yehoshua Z, Bueno-Lopez E, et al. Pharmacokinetic rationale for dosing every 2 weeks versus 4 weeks with intravitreal ranibizumab, bevacizumab, and aflibercept (vascular endothelial growth factor 
Trap-eye). Retina 2012;32:434-57.

8. Browning DJ, Kaiser PK, Rosenfeld PJ, Stewart MW. Aflibercept for age-related macular degeneration: a game-changer or quiet addition? Am J Ophthalmol 2012;154:222-6. [CrossRef]

9. Yoeruek E, Spitzer MS, Tatar O, Aisenbrey S, Bartz-Schmidt KU, Szurman P. Safety profile of bevacizumab on cultured human corneal cells. Cornea 2007;26:977-82. [CrossRef]

10. Ambati BK, Nozaki M, Singh N, Takeda A, Jani PD, Suthar T, et al. Corneal avascularity is due to soluble VEGF receptor-I. Nature 2006;443:993-7. [CrossRef]

I I. Spitzer MS, Wallenfels-Thilo B, Sierra A, Yoeruek E, Peters S, Henke-Fahle S, et al; Tuebingen Bevacizumab Study Group. Antiproliferative and cytotoxic properties of bevacizumab on different ocular cells. Br J Ophthalmol 2006;90:I3I6-2I.

12. Luthra S, Narayanan R, Marques LE, Chwa M, Kim DW, Dong J, et al. Evaluation of in vitro effects of bevacizumab (Avastin) on retinal pigment epithelial, neurosensory retinal, and microvascular endothelial cells. Retina 2006;26:512-8. [CrossRef]

13. Kernt M, Welge-Lüssen U, Yu A, Neubauer AS, Kampik A. Bevacizumab is not toxic to human anterior- and posteriorsegment cultured cells [Article in German]. Ophthalmologe 2007; 104:965-7I. [CrossRef]

14. Pérez-Rico C, Benítez-Herreros J, Castro-Rebollo M, GómezSangil Y, Germain F, Montes-Mollón MA, et al. Effect of intravitreal ranibizumab on corneal endothelium in age-related macular degeneration. Cornea 2010;29:849-52. [CrossRef]

15. Chiang CC, Chen WL, Lin JM, Tsai YY. Effect of bevacizumab on human corneal endothelial cells: a six-month follow-up study. Am J Ophthalmol 2008;|46:688-9|. [CrossRef]

16. Pérez-Rico C, Benítez-Herreros J, Castro-Rebollo M, Gómez-
SanGil Y, Germain F, Montes-Mollón MA, et al. Endothelial cells analysis after intravitreal ranibizumab (Lucentis) in age-related macular degeneration treatment: a pilot study. $\mathrm{Br} \mathrm{J}$ Ophthalmol 2010;94:267-8. [CrossRef]

17. Bayar SA, Altinors DD, Kucukerdonmez C, Akova YA. Severe corneal changes following intravitreal injection of bevacizumab. Ocul Immunol Inflamm 2010; 18:268-74. [CrossRef]

18. Bakri SJ, Pulido JS, Reid JM, Singh RJ, Snyder MR. Pharmacokinetics of intravitreal bevacizumab(Avastin). Ophtalmology 2007; | |4:855-9. [CrossRef]

19. Cho BM, Choi HY, Lee JE, Lee JS, Oum BS. Differences in corneal thickness and corneal endothelium related to duration in diabetes. Eye (Lond) 2006;20:3 I5-8. [CrossRef]

20. Arslan OS, Doğan I, Ermiş SS, Sakarya Y. İnsüline Bağimli Diyabetes Mellitusda Kornea Endotel Morfolojisinin Diyabetik Retinopati İle İlişkisi. Oftalmoloji Dergisi 2002;9:33-6.

21. Chen WL, Chiang CC, Lın JM, Tsai YY. Effect of bevacizumab on human corneal Endothelial Cells: a six-month follow-up study. Am J Ophtalmol 2008; |46:688-91. [CrossRef]

22. Hosny MH, Zayed MA, Shalaby AM, Eissa IM. Effect of intracameral bevacizumab injection on corneal endothelial cells: an in vivo evaluation. J Ocul Pharmacol Ther 2009;25:5 I3-7.

23. Lichtinger A, Yeung SN, Kim P, Amiran MD, Elbaz U, Slomovic AR. Corneal endothelial safety following subconjunctival and intrastromal injection of bevacizumab for corneal neovascularization. Int Ophthalmol 20I4;34:597-60I. [CrossRef]

24. Kim HK, Kim YS, Lee JW, Shin JP, Sohn BJ. In vivo corneal endothelial safety of intracameral bevacizumab and effect in neovascular glaucoma combined with Ahmed valve implantation. J Glaucoma 2009; 18:589-94. [CrossRef] 